\title{
Uji Ketahanan Bakteri Asam Laktat Hasil Fermentasi Kubis Merah ( Brassica oleracea L.) Pada pH 3
}

\author{
Kevin Viktor Bawolea*,Stella Deiby Umboha*,Trina Ekawati Talleja* \\ Jurusan Biologi, FMIPA, Unsrat, Manado
}

\begin{tabular}{l} 
K A T A K N C I \\
\hline Probiotik \\
Fermentasi \\
Tahan asam \\
Katalase
\end{tabular}

\author{
A B S T R A K
}

Probiotik merupakan mikroorganisme hidup yang jika dikonsumsi dalam jumlah yang tepat dapat memberikan manfaat bagi tubuh. Sebagian besar bakteri asam laktat merupakan bakteri probiotik. Untuk dapat memberikan manfaat yang maksimal bagi tubuh, salah satu kriteria yang harus dipenuhi yaitu mampu bertahan hidup pada kondisi $\mathrm{pH}$ yang rendah. Hal ini dikarenakan bakteri probiotik akan menghadapi kondisi $\mathrm{pH}$ rendah yang terdapat di lambung. Penelitian ini bertujuan untuk menguji kemampuan isolat BAL hasil fermentasi kubis merah untuk bertahan hidup pada $\mathrm{pH}$ 3. Bakteri asam laktat ditumbuhkan pada media MRS agar yang ditambahkan $1 \% \mathrm{CaCO}_{3}$ dengan menggunakan metode sebar (spread) dan dimurnikan menggunakan metode gores (streak). Uji ketahanan asam dilakukan dengan cara isolat diinkubasi pada kondisi $\mathrm{pH}$ 3 dalam media NB kemudian ditumbuhkan kembali pada media NA dengan menggunakan metode spread. Uji dilakukan juga untuk mengamati aktivitas enzim katalase. Hasil penelitian menunjukkan bahwa isolat yang diperoleh dari hasil fermentasi kubis merah mampu bertahan pada $\mathrm{pH} 3$.

KE YW OR D S

Probiotic

Fermentation,

Acid resistance

Catalase

\begin{abstract}
A B S T R A C T
Probiotics is a livinng microorganism that if consumed in the right amount can provide benefits to the body. Most lactic acid bacteria are probiotic bacteria. To be able to provide maximum benefits for the body, one of the criteria that must be met is able to survive at low $\mathrm{pH}$. This is because probiotic bacteria will face low $\mathrm{pH}$ conditions found in the stomach. This study aims to test the effectiveness of BAL isolates from red cabbage fermentation to survie at pH 3. Lactic acid bacteria grown on MRSA media added $1 \% \mathrm{CaCO}_{3}$ by using spread method and purified by using streak method. The acid resistance test was performed by isolate incubated at $\mathrm{pH} 3$ condition in NB medium by using spread method. Test were also conducted to observe the activity of catalase enzymes. The result showed that isolates obtained from red cabbage fermentation were able to survive at $\mathrm{pH} 3$.
\end{abstract}

\section{TERSEDIA ONLINE}

01 Agustus 2018

\section{Pendahuluan}

Probiotik merupakan suplemen berupa mikroba hidup yang memiliki manfaat bagi inangnya dengan cara meningkatkan keseimbangan mikroba di dalam tubuh (Fuller, 1989). Efek fisiologis yang diberikan probiotik yaitu antikolesterol, antihipertensi, mengurangi intoleransi laktosa, anti karsinogenik, mengatasi gangguan saluran pencernaan serta alergi (Ooi dan Min-Tze, 2010). Sebagian besar bakteri asam laktat merupakan bakteri probiotik. Sejumlah BAL dari genus Lactobacillus, Leuconostoc, Pediococcus, Lactococcus, dan Streptococcus telah banyak digunakan sebagai strain probiotik (Ljungh dan Wadström, 2006). Bakteri asam laktat antara lain dapat diperoleh melalui proses fermentasi sayuran. Fermentasi merupakan suatu proses metabolik untuk menghasilkan energi dari senyawa-senyawa organik 
tanpa melibatkan agen pengoksidasi eksogen (Bourdichon et al., 2012). Salah satu bahan utama dalam proses fermentasi sayuran yaitu kubis putih. Hal ini disebabkan kubis putih lebih mudah diperoleh dibandingkan kubis merah, akan tetapi kubis merah memiliki aktivitas antioksidan dan kandungan antosianin yang tinggi dibandingkan dengan sayuran kubis-kubisan lainnya (Yee et al., 2007).

Bakteri asam laktat merupakan mikroorganisme yang menghasilkan asam laktat sebagai metabolit utama (Vasiljevic dan Shah, 2008). Bakteri ini bersifat Gram positif, berbentuk kokus, coccobacilii, atau basil. Bakteri ini memfermentasi karbohidrat untuk membentuk asam laktat, CO2, dan etanol, serta biasanya tidak menghasilkan katalase atau katalase negatif (Vasiljevic dan Shah, 2008). Bakteri asam laktat biasanya lebih toleran terhadap kondisi lingkungan $\mathrm{pH}$ asam (FAO, 1998). Bakteri ini memiliki kemampuan menurunkan $\mathrm{pH}$ makanan sehingga pada kondisi $\mathrm{pH}$ yang rendah pertumbuhan mikroorganisme lain termasuk bakteri patogen akan terhambat (Karthikeyan dan Santosh, 2009). Hal pertama yang dihadapi bakteri probiotik ketika ditelan adalah kondisi $\mathrm{pH}$ rendah yang terdapat di lambung (Bron et al., 2004). Penelitian ini bertujuan untuk menguji kemampuan isolat BAL hasil fermentasi kubis merah untuk bertahan hidup pada $\mathrm{pH} 3$.

\section{Material dan Metode}

\section{Alat dan Bahan}

Alat yang digunakan dalam penelitian ini yaitu tabung reaksi, mikro pipet, tabung Eppendorf, mason jar, autoclaff, labu erlenmeyer, cawan petri, pipet tetes, gelas ukur, mikroskop, refrigerator, jarum oose, bunshen, inkubator, magnetic stirer, laminar airflow, kompor listrik, sentrifuse, masker, sarung tangan, kamera, dan gunting.

Bahan yang digunakan dalam penelitian ini yaitu kubis merah, MRSA (de Mann Rogose and Sharpe Agar), natrium asam taurodeoksikolat, alkohol, Aquades, $\mathrm{CaCO}_{3}$, gliserol, spritus, dan aluminium foil.

\section{Isolasi Bakteri Asam Laktat}

Kubis merah pertama-tama dibersihkan terlebih dahulu tanpa dibilas dengan air, lapisan luar dari kubis merah dikeluarkan dan bagian dalam dipotong-potong menjadi potongan kecil. Bagian yang telah dipotong-potong dimasukkan ke dalam botol kaca (Mason jar) steril yang kemudian diisi dengan larutan garam 15\%. Mason jar kemudian ditutup rapat dan difermentasikan selama 7 hari. Cairan hasil fermentasi diambil menggunakan mikropipet sebanyak $100 \mu \mathrm{l}$ kemudian disebarkan secara merata diatas media MRSA yang mengandung $\mathrm{CaCO}_{3} 1 \%$. Media MRSA kemudian diinkubasi pada suhu $37^{\circ} \mathrm{C}$ selama dua sampai tiga hari. Koloni BAL yang berhasil tumbuh pada MRSA akan menghasilkan zona bening yang dapat diamati. Masing-masing koloni yang menghasilkan zona bening selanjutnya dimurnikan dengan metode gores untuk memperoleh bakteri tunggal. Bakteri tunggal kemudian dipindahkan pada media agar miring untuk digunakan sebagai isolat uji.

\section{Identifikasi Bakteri Asam Laktat}

Identifikasi yang dilakukan meliputi identifikasi secara makroskopik yaitu mengamati bentuk morfologi koloni dan uji katalase. Identifikasi secara makroskopik dilakukan dengan cara mengamati secara langsung bentuk dan morfologi koloni yang tumbuh, meliputi bentuk, warna, tepi, permukaan dan elevasi. Selanjutnya uji katalase dilakukan dengan cara meneteskan 1 sampai 2 tetes larutan pada bakteri yang telah dioleskan sebanyak 1 ose di atas kaca obyek. Jika terbentuk gelembung berarti bersifat katalase positif sedangkan jika tidak terbentuk gelembung berarti bersifat katalase negatif.

\section{Uji Ketahanan Asam Isolat}

Bakteri uji ditanam dalam media NB (nutrient broth) sebanyak $1 \mathrm{ml}$ dalam tabung Eppendorf lalu diinkubasi selama 1 x 24 jam. Bakteri yang berumur 24 jam kemudian ditetesi $\mathrm{HCl}$ yang telah diencerkan sebanyak $10 \mu \mathrm{l}$ pada tiap tabung Eppendorf sehingga mencapai $\mathrm{pH} 3$, kemudian diinkubasi pada suhu $37^{\circ} \mathrm{C}$ selama tiga jam. Setiap jam, sebanyak $200 \mu \mathrm{l}$ inokulum disebar di atas media MRSA dan diinkubasi pada $37^{\circ} \mathrm{C}$. Pengamatan dilakukan selama lima hari. Kontrol untuk uji ketahanan terhadap $\mathrm{pH}$ rendah berupa isolat yang ditumbuhkan dalam NB selama 24 jam namun tidak diberi perlakuan $\mathrm{HCl}$ dan ditumbuhkan pada media MRSA.

\section{Hasil dan Pembahasan \\ Isolasi Bakteri Asam Laktat}

Bakteri asam laktat telah berhasil diisolasi dari kubis merah. Cairan hasil fermentasi terlihat berwarna ungu pekat, yang merupakan warna dari antosianin kubis merah.

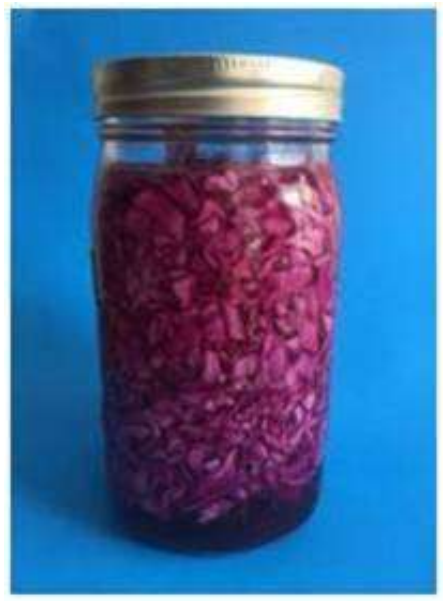

Gambar 1. Hasil fermentasi kubis merah selama 7 hari.

Cairan fermentasi kubis merah ditebar di media MRSA yang mengandung $\mathrm{CaCO}_{3} 1 \%$. Di sekitar koloni bakteri dapat diamati zona bening akibat terbentuknya Ca-laktat, yang menandakan bahwa asam laktat yang dihasilkan oleh BAL pada media MRSA telah bereaksi dengan $\mathrm{CaCO}_{3}$. Koloni bakteri yang ditanam pada media MRSA tanpa $\mathrm{CaCO}_{3}$ tidak 
menghasilkan zona bening. Koloni kemudian dimurnikan menggunakan metode gores kemudian dipindahkan dan disimpan dalam media agar miring untuk dilakukan uji kemampuan isolat bertahan hidup pada $\mathrm{pH} 3$.

\section{Identifikasi Bakteri Asam Laktat}

Isolat yang telah diisolasi dan dimurnikan kemudian diidentifikasi secara makroskopis yaitu dengan cara mengamati bentuk koloni, warna koloni, tepian koloni, dan permukaan koloni. Koloni bakteri yang diperoleh dari hasil fermentasi kubis merah memiliki ciri-ciri berwarna putih susu, bentuk bulat, tepian licin, dan permukaan cembung.

Tabel 1. Karakteristik morfologi isolat bakteri hasil fermentasi kubis merah secara makroskopik

Nama Karakterisasi Morfologi

\begin{tabular}{lllll}
\cline { 2 - 4 } & Bentuk & Warna & Tepi & Permukaan \\
& Koloni & Koloni & Koloni & Koloni \\
Isolat & Bulat & Putih & Licin & Cembung \\
1 & & Susu & & \\
\hline
\end{tabular}

Hasil uji katalase menunjukkan bahwa isolat hasil fermentasi kubis merah merupakan bakteri katalase negatif. Hal ini terlihat ketika isolat dioleskan pada larutan $\mathrm{H}_{2} \mathrm{O}_{2}$ tidak menimbulkan reaksi berupa gelembung oksigen (Gambar $2 \mathrm{~A}$ ). Ini menandakan bakteri tidak menghasilkan enzim katalase yang akan mengubah $\mathrm{H}_{2} \mathrm{O}_{2}$ menjadi air dan oksigen. Hasil ini dibandingkan dengan hasil uji katalase bakteri Escherichia coli yang menghasilkan gelembung ketika bakteri dioleskan pada $\mathrm{H}_{2} \mathrm{O}_{2}$ (Gambar 2B) yang menandakan bahwa bakteri E.coli merupakan bakteri katalase positif dan menghasilkan enzim katalase (El-Hadedy dan ElNour, 2012).

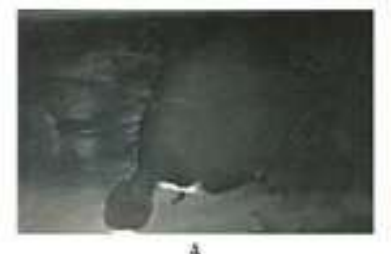

A

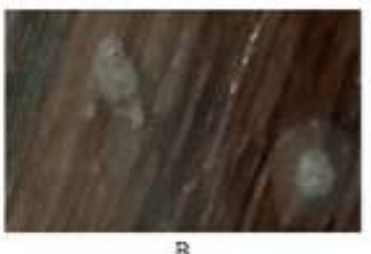

B
Gambar 2. Hasil uji katalase isolat BAL katalase negatif $(A)$ dan Eschericia coli sebagai kontrol

\section{Uji Ketahanan Asam} katalase positif (B).

Seperti yang dapat dilihat pada Tabel 2 kemampuan bertahan hidup dan kecepatan tumbuh dari isolat BAL berbeda sesuai dengan lama inkubasi pada keasaman yang tinggi. Semakin lama waktu inkubasi pada $\mathrm{pH}$ rendah maka kemampuan bertahan hidup dan kecepatan tumbuh bakteri pada media MRSA semakin berkurang. Perbandingan antara kontrol yang tidak diinkubasi pada $\mathrm{pH} 3$ dan yang diberi perlakuan terlihat dari segi kecepatan tumbuh dan kemampuan bertahan hidup isolat ketika ditumbuhkan pada media MRSA. Dapat diamati bahwa BAL kontrol tumbuh dengan baik selama lima hari pengamatan dari segi jumlah koloni dan kecepatan tumbuh, sementara isolat yang diberi perlakuan pada $\mathrm{pH} 3$ memberikan hasil yang berbeda. Pada hari pertama pengamatan, terdapat koloni yang tumbuh pada perlakuan 1 namun jumlah koloni yang tumbuh sangat sedikit dan memiliki ukuran yang lebih kecil dibandingkan kontrol. Pada hari pertama, perlakuan 2 dan perlakuan 3 belum bertumbuh. Pada hari kedua pengamatan, perlakuan 1 diamati ukuran koloni semakin membesar, pada perlakuan 2 mulai terlihat beberapa koloni bertumbuh dibagian tengah petri namun jumlahnya hanya sedikit, dan perlakuan 3 masih belum ada koloni yang bertumbuh. Pada hari ketiga pengamatan, terlihat jumlah koloni yang tumbuh pada perlakuan 1 semakin banyak sementara perlakuan 2 dan 3 tidak terdapat perbedaan. Pada hari keempat pengamatan tidak terdapat perbedaan dari ketiga perlakuan, dan pada hari kelima pengamatan tidak terdapat perbedaan pada perlakuan 1 dan 2 namun terlihat koloni mulai tumbuh pada perlakuan 3 .

Menurut Papadimitriou et al. (2016), BAL relatif toleran terhadap $\mathrm{pH}$ yang rendah. Untuk dapat dijadikan sebagai probiotik, maka BAL harus mampu bertahan pada $\mathrm{pH}$ rendah, karena keasaman lambung berkisar antara $\mathrm{pH}$ 2,0-4,0 diakibatkan oleh produksi $\mathrm{HCl}$. Akan tetapi, akan terdapat kerusakan sel dan penurunan viabilitas pada bakteri yang terpapar $\mathrm{pH}$ rendah sehingga penurunan jumlah koloni dapat terjadi (Susanti et al., 2007). Bakteri asam laktat dapat bertahan pada kondisi lingkungan dengan $\mathrm{pH}$ rendah karena memiliki mekanisme untuk mempertahankan kondisi pH di dalam selnya, yaitu lebih netral dibandingkan dengan $\mathrm{pH}$ di lingkungan (Halim, 2013).

Tabel 2. Hasil uji ketahanan isolat BAL hasil fermentasi kubis merah terhadap $\mathrm{pH} 3$.

\begin{tabular}{lllllll}
\hline & \multicolumn{5}{c}{ Pengamatan } \\
\cline { 2 - 6 } Perlakuan & Hari & Hari & Hari & Hari & Hari \\
& 1 & 2 & 3 & 4 & 5 \\
\hline $\begin{array}{l}\text { TanpaHCL } \\
\text { (Kontrol) }\end{array}$ & +++ & +++ & +++ & +++ & +++ \\
$\begin{array}{l}\text { Inkubasi } \\
\text { Jam HCl }\end{array}$ & 1 & + & + & ++ & ++ & ++ \\
$\begin{array}{l}\text { Inkubasi } \\
\text { Jam HCl }\end{array}$ & 2 & - & + & + & + & + \\
$\begin{array}{l}\text { Inkubasi } \\
\text { Jam HCl }\end{array}$ & 3 & - & - & - & - & + \\
\hline
\end{tabular}

\section{Keterangan:}

+++ : Kecepatan tumbuh dan kemampuan bertahan hidup isolat tinggi

++ : Kecepatan tumbuh dan kemampuan bertahan hidup isolat sedang

$+\quad$ : Kecepatan tumbuh dan kemampuan bertahan hidup isolat rendah

\section{: Isolat tidak tumbuh}




4. Kesimpulan
Berdasarkan penelitian yang telah dilakukan
maka dapat disimpulkan bahwa Isolat bakteri
asam laktat hasil fermentasi kubis merah dapat
bertahan pada pH 3 .

\section{Daftar Pustaka}

Bourdichon, F., Casaregola, S., Farrokh, C., Frisvad, J.C., Gerds, M.L., Hammes, W.P., Harnett, J., Huys, G., Laulund, S., Ouwehand, A., Powell, I.B., Prajapati, J.B., Seto, Y., Schure, E.T., Van Boven, A., Vankerckhoven, V., Zgoda, A., Tuijtelaars, S., Hansen, E.B. 2012. Food fermentations: Microorganisms with technological beneficial use. Int.J. Food Microb. 154(3):87-97. Doi:10.1016/j.ijfoodmicro.2011.12.030.

Bron, P.A., Marco, M., Hoffer, S.M., Mullekom, E.V., de Vos, W.M., Kleerebezem, M. 2004. Genetic characterization of the bile salt response in Lactobacillus plantarum and analysis of responsive promoters in vitro and in situ in the gastrointestinal tract. J. Bacteriol. 186: 78297835.

El-Hadedy, D., El-Nour, S.A. 2012. Identification of Staphylococcus aureus and Escherichia coli isolated from Egyptian food by conventional and molecular methods. J. Gen. Eng. Biotech. 10(1):129-135.

Food and Agriculture Organization of the United Nations Rome. 1998. Fermented Frutis and Vegetables : A Global Perspective. Fao Agricultural Services Bulletin No. 134. Rome. Italy.

Fuller, R. 1989. Probiotics in man and animals. Journal of Applied Bacteriology, 66(5):365378.

Halim, C.N., Zubaidah, E. 2013. Studi Kemampuan Probiotik Isolat Bakteri Asam Laktat Penghasil Eksopolisakarida Tinggi Asal Sawi Asin (Brassica juncea). Jurnal Pangan dan Argoindustri. 1(1):129-137.

Karthikeyan, V., Santosh, S.W. 2009. Isolation and Partial Characterization of Bacteriocin Produced from Lactobacillus plantarum. African Journal of Microbiology Research. 3(5):233-239.

Ljungh, A., Wadström, T. 2006. Lactic acid bacteria as probiotics. Curr. Issues. Intest. Microbiol.7(2):73-89.

Ooi, L.G., Min Tze, L. 2010. Cholesterol-lowering effects of probiotics and prebiotics : A review of in vivo and in vitro findings. Int.J.Mol.Sci, 1(1): 2499-2522.

Susanti, I., Retno, W.K., Fatim, I. 2007. Uji Sifat Probiotik Bakteri Asam Laktat Sebagai Kandidat Bahan Pangan Fungsional. Jurnal Teknol. dan Industri Pangan, Vol XVIII No.2 Th. 2007.

Vasiljevic, T., Shah, N.P. 2008. Probiotics -from Metchnikoff to bioactive. International Dairy Journal 18: 714-728.

Yee, L.W., Ikram, E.H.K., Jalil, A.M.H., Ismail, A. 2007. Antioxidant capacity and phenolic content of selected commercially available cruciferous vegetables. Mal. J. Nutr. 13(1):71-80. 